\title{
REFLECTIONS ON FATALISM IN THE STREETS OF THE ROMANIAN POST-SOCIALIST CITY. A CASE STUDY OF EROILOR DE LA TISA STREET, TIMIŞOARA
}

\author{
Sorina VOICULESCU \\ Faculty of Chemistry, Biology and Geography, West University of Timişoara, ROMANIA \\ sorina.voiculescu@e-uvt.ro \\ DOI: http://doi.org/10.23740/TID220171
}

\section{ABSTRACT}

This paper presents reflection and analysis about the ways in which public spaces in contemporary Romanian cities have been evolving, highlighting a concern with the alarming growth in gambling facilities over the last decade. In order to understand the gambling environment, and its implicit discourse, I used participative observation over a span of ten years and interviews with gamblers and their relatives.

This qualitative data is analysed through the lens of Mary Douglas' Cultural Theory, with special accents on fatalist way of life, which characterizes the group of gamblers. Gambling facilities act like codes deciphered by different groups of players, in turn enacting a kind of control upon their social and private lives. In this process, the players become fatalists, who rely on fate or perceived chance, limiting their autonomy and controlling the choices they make. Betting shops and pawn shops replaced the once traditional community shops, promoting the gambling industry, which prospers on the players' addictive behaviour. Addiction is responsible for criminality in different forms and for substance abuse. With the almost daily exposure to this environmental and social setting, adolescents and youth internalize gambling as part of their social capital and their identity. In the absence of any local policies, the implicit message sent by local authorities to the public is that profit maximization prevails against all odds.

\section{INTRODUCTION}

Cities represent the quintessential image of a nation. Layers after layers of urban civilisation stand proof for the values, norms and ways of life shared by various generations of citadins in the process of identification with the lived environment. Our lived environment is created and recreated by social and cultural relations. Therefore, each generation has its chance to create and reinvent the city, to choose what the city should look like and, accordingly, to generate those particular social and cultural relations connected to the space it inhabits. Successive ways of life shape the living environments in which we recognize ourselves, according to the meaning we give them. When we attach feelings to certain spaces, they turn into places (Lefebvre, 1991). Relph (1976, p. 141) considers that most essentially places are "significant centres of our immediate experiences of the world" and "that the more profoundly inside a place a person feels, the stronger will be his or her identity with the place" (Relph, 2000, apud Seamon \& Sowers, 2008, p. 45). 
As Norton \& Walton-Roberts (2014, p. 283) explain, today, place and identity are shaped in the process of spatial change and vice versa. These changes are fed either traditionally, by governments and other institutions of control and power or, more recently, by the global and transnational culture. Therefore spatial change can have a major role in the process of shaping identities. Different and various media channels, almost compulsory access to mobile telecommunication and wireless internet access play a very important role in this process and keep the individual trapped in the virtual space, one click away from virtual spaces and places. Sometimes those virtual places have representations in the real urban space and they contribute to shaping somehow hybrid identities, masculinities and femininities luring with success, fortune, and perfection.

Thinking of generational contributions to the city and also of what cities offer to the younger generations, this paper represents a preliminary work, a personal reflection, based on consecutive observations on gambling facilities that insidiously mushroomed in Romanian cities. Step by step, replacing shops that went bankrupt because of the competition posed by supermarkets, gambling facilities have become part of urban dwellers' everyday lifestyle. Almost overnight, they became the sole attraction in most post-socialist Romanian districts, competing with one another and promising instant access to cash, in the context of lower living standards, especially after 2008. My reflections evolved around several questions: Whom do all these gambling facilities represent and how do they relate to different structures of power? What are the messages encoded in the social practices they generate? How do they relate to the construction of fatalism in the public space?

The aim of this paper is to introduce the theme of ways of life as part of spatial practices and to exemplify them through the most harmful, i.e. fatalism.

\section{CHALLENGES FOR ROMANIAN POST-SOCIALIST CITIES AND CITADINS (OR: HOW ROMANIAN CITIES HAVE HAD TO REINVENT THEMSELVES)}

The transition from state-socialism to capitalism brought multiple changes that Romanian cities had to cope with. The once 'closed' cities were opened for migrants in search of jobs, but in the context of closing socialist heavy industry, leaving brownfields behind and favouring greenfield developments. The liberalisation of the housing market transformed urban society from a society of renters into one of (poor) owners, due to an emerging housing market, which triggered suburbanization, gentrification, and urban sprawl. Urban traffic and urban transportation, in the context of scarce parking lots, have been on the agenda of every urban government. On top of all these transformations, the economic recession starting in 2008 brought additional difficulties to the already difficult transition and the citadins recently acquainted with capitalist consumerism developed new alternative strategies of consumption, with the tacit agreement of the state, which became the beneficiary of important revenues due to taxes.

Thinking of the contemporary Romanian city - after post-socialism - one should observe the multiple emerging themes coming out of multiple contemporary social and cultural practices. Researchers dealt with different aspects of change such as urban restructuring (Jucu, 2015) and urban shrinkage caused by deindustrialization (Popescu, 2014; Prasca et al., 2013; Rink et al., 2014), analysis of subtle changes in street names (Crețan \& Matthews, 2016), comparative studies on Eastern and Western European cities concerning urban form and urban planning 
policies and practices (Sandu, 2016), public transportation and sustainable urban mobility plans (Tomasciuc et al., 2016), urban sprawl (Grădinaru et al., 2015), urban dereliction (Voiculescu \& Jucu, 2016), etc.

Beside these already classic aspects of urban changes, there is one that has posed me observational as well as reflective problems in a time span that covers the last decade or so. It is about the public space (half public, half private) that very often fails to keep up with other urban developments and changed in a way that reflects poverty, chance, and absence of particular urban policies. It is about the sports betting and pawn shops that have mushroomed in Romanian cities, associated to important socio-spatial and territorial behaviours and practices.

\section{RESEARCH METHODS}

This paper draws its research methods from Cultural Geography in order to understand the meaning of places, and the sense of belonging that people acquire through and within their exposure to culture. It is culture that feeds our identification to a certain place. Culture as a way of life and human behaviour have nothing to do with our genetic characteristics (Boas, 1888). It is a sequential, temporal construct that we identify with (or not), a set of meanings and symbols that structure our lived environments, which in turn influence the construction of the cultural capital. Sometimes, transformations of our lived environments determine feelings of existential insideness and outsideness (Seamon \& Sowers, 2008). The aim of this paper is to raise awareness about the way of life that betting and pawn shops generate in the process of our identification to certain places.

The first method was successive 'participative' observation done over the last 10 years in Timișoara, especially in Eroilor de la Tisa Street. My participation was not direct, because I am not a gambler and I have certain difficulties in appropriating gambling methods or specific understanding in sports (especially soccer). Therefore, I used to observe the betting shops from the outside and see who their customers were, what their attitude was, their facial expressions, and even observe their state of mind. From the very beginning, I had a particular feeling of exclusion because it was a male dominated space, with boys wearing hoods in order to conceal their identity, with blurred windows and flashing sings that respectively lured in customers and conferred them safety and privacy from the 'world outside'. I was observing the betting shops at different times of the day, to the point that I could 'bet' what was the destination of particular groups of boys and also their age (below 18 years old).

As Laurier (2010, p. 150) points out: "The strengths of participant observation [...] it is easy to do and it provides a more direct access to phenomena than some of the more complex methodologies of social science. It allows you to build detailed descriptions from the ground up that should be recognizable to the groups whose lives you have entered into. Its limits are that it does not have a handle that you can turn to make results pop out. Nor can it be shoe-horned in as a replacement for statistical methods since it will provide only very weak answers to the kinds of questions that could be hypothesis tested."

The second method I used was that of free and structured interviews with participants to gambling or with their relatives (mothers, girlfriends, other persons affected by the acts of gambling). This method is "... about listening. It is about paying attention. It is about being open 
to hear what people have to say. It is about being non-judgmental" (Krueger \& Casey, 2000, apud Longhurst, 2010, p. 103).

The location of my observations was either in Eroilor de la Tisa Street or in Calea Aradului Street, in Timișoara. The interviews were taken in private places, away from the gambling areas and respondents were from Timișoara and Oradea (all of them gambling in Timișoara, in Eroilor de la Tisa Street). Even if the locations were different, the strategies were similar, as explained in this article.

\section{MARY DOUGLAS AND THE CULTURAL THEORY - HIGHLIGHTING FATALISM}

Douglas' Cultural Theory (1978) explains how our social life, actions, and desires are culturally biased (Mamadouh, 1999, p. 396). In the work "Natural Symbols Explorations in Cosmology", Douglas (2002) elaborates the grid and group theory. Thinking on Bernstein's arguments, she considers that all groups of people are bound together by restricted codes that can be deciphered only by the members of the group. "The code enables a given pattern of values to be enforced and allows members to internalize the structure of the group and its norms in the very process of interaction" (Douglas, 2002, p. 54). The structure of relations within society is confusing and therefore not necessarily clear to all its members. In the same vein, codes are restricted and they sustain particular social forms. In this process, codes are instruments of both control and communication. Codes can be compared to rituals and rituals create solidarity. From this perspective, "in any social group there are some areas of social life more responsible for policy decisions and more exposed to the need to communicate with outsiders" (Douglas, 2002, p. 55).

Following Bernstein's diagram, Douglas (2002, p. 56) explains how the location of grid and groups within the diagram speak about the interaction of individuals within two social dimensions: order and pressure. In other words, individuals live according to their will or according to the pressures posed by stronger people. In Douglas' words $(2002$, p. 59): “When the pressures are strong and when they uphold a set of classifications, then a process of mutual reinforcement is at work. Such a social system is likely to remain stable, unless counter-pressures develop from outside or unless new knowledge weakens the credibility of the classifications [...]. A society that is spread across the diagram at a low level of classification is likely to become one that is continually subject to political upheaval and a changing profile for the distribution of authority."

Groups have different traits according to the social order. There are groups that have a hierarchical internal organization, with "less trouble with controlling their members, less reason for worrying about defection". There are also egalitarian groups characterized by the absence of leadership, with excellent skills at solving organizational problems. "The problems start with a cultural enclavism, an initial decision to withdraw as a group from the wider society of which it was a part. The true enclave is in disagreement with the outside world" (Douglas, 2002, p. XX). The more such a community has dissident views, such as refusing military service, demanding separate education, refusing to vote or serve in public office, the less it can count on outside help. It cannot bring in the police to enforce what is not enforceable in the larger society (Douglas, 2002, p. XXI).

Of the ways of life analysed by Douglas, I shall focus more on fatalists and their grid and group dimension because this is the type of culture promoted by the betting shops, pawn shops and casinos. Due to their replicated occurrences in the public space, they generate a way of life based on fate, chance and endured outcomes (versus results that people are working for). Fatalists blame and praise fate, they have limited individual autonomy, they isolate themselves in a world they 
cannot control, finding their own ways of survival (Stoker, 2004, apud Veiga et al., 2011). The fatalist way of life can be avoided promoting the group dimension. When/if quality and quality mechanisms are assessed, the group dimension is enhanced while too many rules enforce the grid dimension (Veiga et al., 2011). Thompson et al. (1990) consider fatalism as a source of renewal for the active ways of life. Fatalists oppose egalitarians "and egalitarians are always on the lookout for fatalists to rescue" (Jensen, 1999, p. 183). Some traits of the fatalist culture and of fatalist persons that are very relevant for our study are: individualism, apathy of the individuals who do not help others nor help themselves, a need to see failure in others so that they praise their own success, isolation, avoidance, lack of role models, uncertainty, and an incapacity of managing or getting resources.

\section{FINDINGS AND DISCUSSION}

Who are we related to the space we live in? How does that space represent us, our sense of belonging, and our aspirations? The answer to these questions will be given as a result of the reflections of a cultural geographer emotionally involved in and observing in a participatory manner the same space she has lived in for the past 40 years. My observations were related to the way in which community stores (corner stores, food stores, markets, vegetables stores, confectioneries, etc.) were insidiously replaced by other "recreational" facilities that address certain groups of people, with particular expectations and needs, other than the needs and expectations that the community had ten years ago. And in doing so, they develop a daily routine (other than shopping for food) that belongs to a certain way of life, which supports and is supported by betting shops, casinos and pawn shops. What is the way of life that is reflected/promoted in our new urban public spaces? Who is the public that these locations address?

\section{About betting shops, casinos, and pawn shops}

My daily journey in the Street of the Tisa Heroes (Strada Eroilor de la Tisa) made me pose different questions about pawn shops, betting shops and casinos - their territoriality, associations within the same block, as well as the competition involved (Figure 1 \& Figure 2). Actually, moving around Timișoara, I observed the same association targeting different places: the university campus, schools, high-density areas - usually, the socialist districts with blocks of flats that allowed shopping areas at ground level, spaces with no other forms of leisure activities.

According to Griffiths (2009, p. 8), gambling shops are the most common forms of offline commercial gambling in Europe where various forms of betting take place: "sports betting which is characterized by wagering of money on horse races, greyhound races, football matches, etc. usually in a betting shop in an attempt to win money; [...] non-sports betting, characterized by wagering of money on a non-sporting event (such as who will be evicted from the 'Big Brother' house), usually done in a betting shop in an attempt to win money; [...] roulette - a game in which players try to predict where a spinning ball will land on a 36-numbered wheel. This game can be played with a real roulette wheel (e.g. in a casino) or on an electronic gaming machines (e.g. in a betting shop); [...] slot machines (e.g. fruit machines, fixed odds betting terminals) [...]. These are stand-alone electronic gaming machines that come in a variety of guises. These include many different types of 'slot machine' (typically played in amusement arcades, family leisure centres, casinos, etc.) and fixed odds betting terminals typically played in betting shops." 


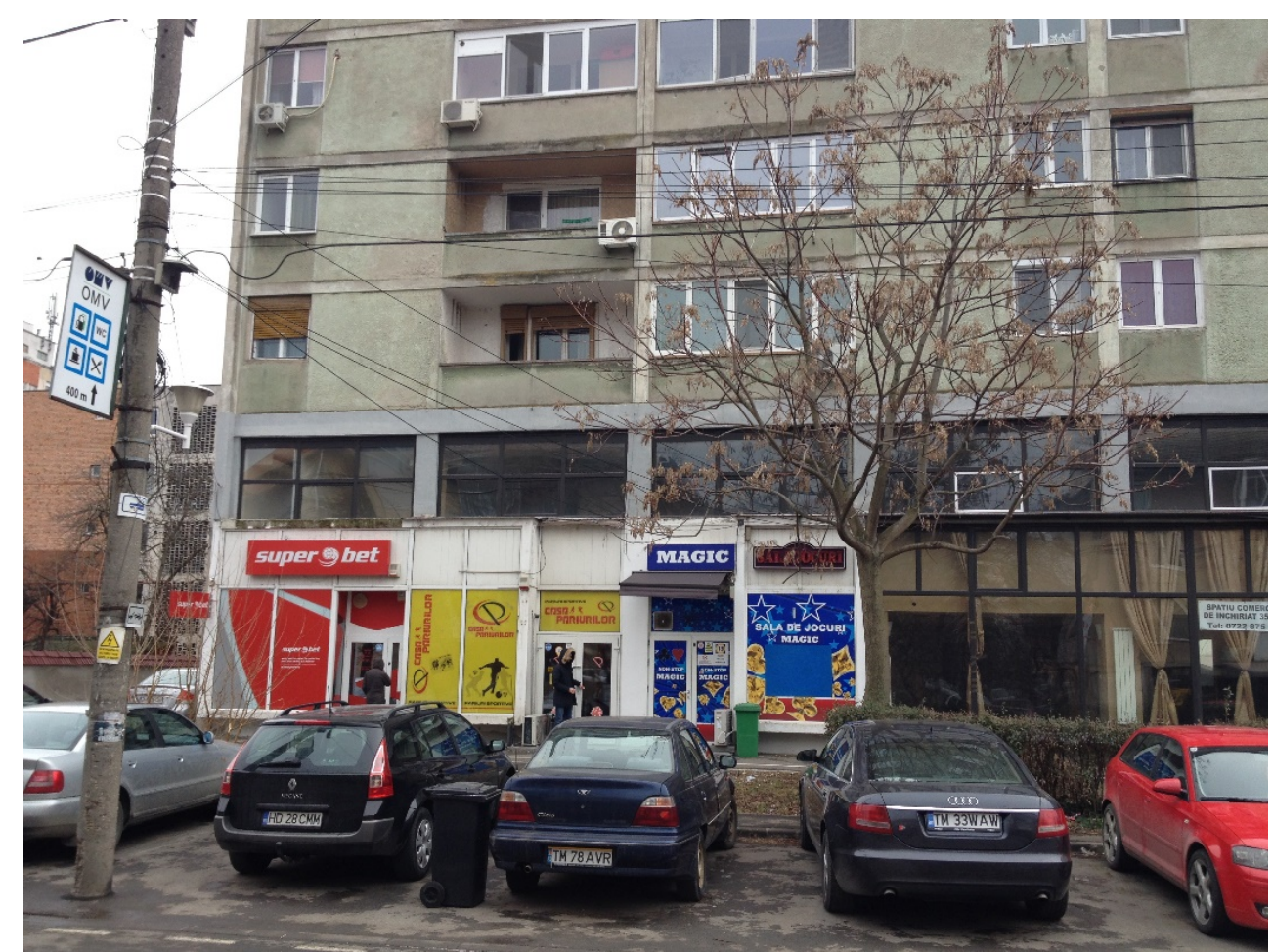

Figure 1: Association of gambling facilities in Eroilor de la Tisa Street (from left to right): Super Bet (sports betting), Casa pariurilor (Gambling house - sports betting), and Magic (slot machines, roulette). All have the same address: Eroilor de la Tisa Street 10-12 Source: Sorina VOICULESCU, 2017

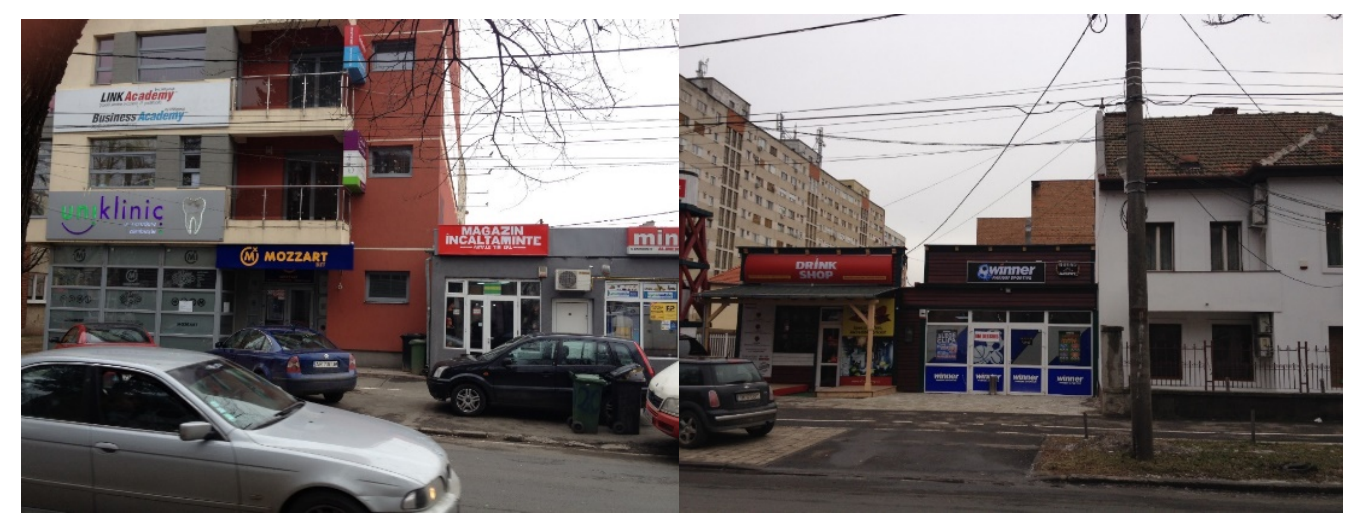

Figure 2: Mozzart (sports betting), Eroilor de la Tisa Street 18 (left); Winner (sports betting), Eroilor de la Tisa Street 18 (right)

Source: Sorina VOICULESCU, 2017

The gambling industry

Gambling as an industry is comparable to the industries of diamond and arms dealers, which raise the interest of organized crime because of high profits and higher and higher shares of markets. Together, the national lotteries and the private gambling houses had a profit of 250 billion \$ in 2004 (Pastia, 2005) and 423 billion \$ in 2014 (Casota, 2016), which encourages the 
state to take the largest shares, with the profit being reinvested in order to support arts, sports, and scientific research. Sport betting shops are sometimes accomplices of corrupt referees, who sell soccer games - some soccer clubs are sometimes controlled by organized crime, who offer low salaries in exchange of important shares of the profit obtained by sport betting shops (Pastia, 2005).

Casinos became the $12^{\text {th }}$ most important industry in Romania in 2014. According to a PwC report in 2012, Romania gained 700 million $€$ from gambling and the state received 333 million $€$ in taxes. In the report, the slot-machine market was estimated at 400-500 million $€$, representing $51 \%$ of the gambling market and $16 \%$ of the income of sports betting shops. According to Dan Ghiță, president of ROMBET (Casota, 2016), slot machines now represent $60 \%$ of the gambling market, followed by sports betting at $20 \%$ ), and online gambling, national lottery and other gambling games making up for the remaining $20 \%$ of the market.

\section{Addiction, gambling, and the environment}

"Gambling represents a type of addictive behavior that has both a social and an environmental cause. It is the result of social relations, social behavior which are embedded in specific environmental and cultural settings" (Reith \& Dobbie, 2011, p. 483). Social networks such as friends, colleagues and families have a decisive role in creating an addictive behaviour with chances that exposure in early childhood within a family predisposes a person to developing a 'gambling identity' (Reith \& Dobbie, 2011, p. 489).

From the point of view of Cultural Theory, especially the fatalist way of life, we should think about how and why fatalism contributes to policy making and, through policies, contributes to place making. Gambling and the revenues that the state gets from gambling are the results of fortune/hazard. For the players, results are endured not produced, and so are the revenues for the government (gambling taxes) as already determined.

Addiction to gambling is the type of behaviour that the gambling industry relies on. According to Pastia (2005), there are multiple factors that encourage addictive behaviour, such as the social context, the individual's psychology, the genetic heritage, as well as quick earnings. Addiction can be prevented by policies and regulations that limit the earnings as well as by the limitation of dangerous games.

The New York Times presents the result of a study done by Buffalo University, which states that "after examining 15 types of legal gambling, the researchers came to a striking conclusion: Casino gambling had by far the most harmful effects on people at the lower end of the income ladder" - i.e. harming the poor, driving them deeper into poverty, with more chances to loose than rich customers have. "Exposure to gambling facilities in neighborhoods and local communities accounts for early 'lived' experiences of children and adolescents with gambling machines conducive to addictive behavior" (Reith \& Dobbie, 2011, p. 486).

The stories told by the interviewed persons - aged $20-25$ years- revealed the same strategies used as adolescents in order to enter the gambling arena. One similar trait of the persons was their height and their looks. At 14, they looked older, therefore no identity card was asked when entering the slot machine or roulette shops or, more often, the sports betting shop. The absence of control was a matter of pride for the adolescents and then an incentive to continue gambling. Daily pocket money was either multiplied or lost in this process. The children used to gamble in sports betting shops in the proximity of their schools and one in the shops in Eroilor de la Tisa 
Street, next to the university campus. Gambling became part of their daily routine, the kind of interaction that later generated an addictive behaviour.

There are multiple causes that facilitate gambling in adolescents. From the territorial perspective, there is the accessibility of gambling venues. One of the interviewed men reported that the longest period he restraint from gambling was during an ERASMUS stage in Madrid where no gambling facilities were available within a 2 hours walking distance. He realized the tragic/comic aspects of the situation and somehow acknowledged his addictive behaviour. This is an example of how a person can refrain from gambling (in this situation) if the environment is not favourable. This never happened again back home, where gambling facilities mushroomed in all Romanian cities.

Studies show why adolescents gamble and many of the reasons described in them (Messerlian \& Derevensky, 2007, p. 101) are reflected in the present social and psychological environment in Romania. So adolescents gamble because gambling venues are accessible (as seen in our case studies), because they are cool if they gamble and being cool is part of their daily routine (with special concern for look and clothing) and because they want to imitate the adult behaviour. Nevertheless, society should be concerned because gambling has significant public health outcomes such as depression and suicide, insomnia, school absenteeism and, very often, the gambler develops other addictions. The consequence are three tiered: individual, family and friends and financial, with significant loses. Among these, there can be mentioned the "emotional harm, lying, stealing, reduced quality time with family and friends, financial impact" (Messerlian \& Derevensky, 2007, p. 101). Other studies show how gambling determines development of impulsivity in urban male youth (Liu et al., 2013). The studies show that impulsivity development was very much connected with gambling issues.

\section{Pawn shops}

Pawn shops complete the landscapes of chance, addiction and poverty, offering short-term credit. They are available to anyone and the most aggressive of them are open 24-hours a day. They are alternative sources of financing and they have proliferated in all towns and cities of Romania during the last 15 years, standing proof of the failure of the banking system to address the poor. The items pawned range from jewellery, cell phones to laptops and other electronic appliances.

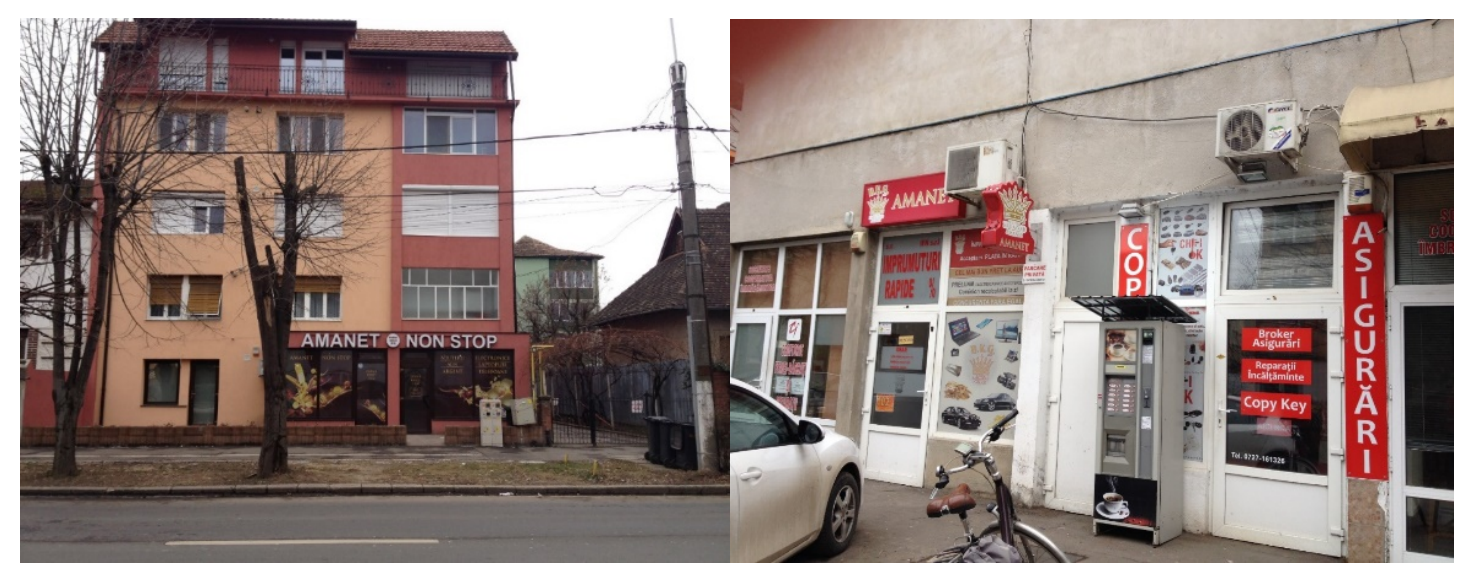

Figure 3: Pawn shops with attractive offers for gamblers (left \& right) 
One of the interviewed boys declared that he repeatedly pawned his cell phone in the pawn shop in Eroilor de la Tisa Street, using different strategies to justify the missing phone in front of his parents. Actually, the successful businesses in this area rely on students from the university campus, which determined both the multiplication of the betting shops, as well as that of the pawn shops. The more profitable the business, the longer their opening hours. The first pawn shop to open in Eroilor de la Tisa Street offers its services 24 hours/day (Figure 3 left). On its blurred windows, it advertises for gold and silver jewellery and electronic appliances. One block away, a one minute walk from the Faculty of Law, the newer pawn shop (Figure 3 right) advertises for even more amazing items, i.e. cars and the best price for gold.

\section{CONCLUSIONS}

The example of gambling facilities in Eroilor de la Tisa Street in Timișoara is a déjà vu for all cities and towns in post-socialist Romania. From the territorial perspective, this is the first example, more a personal reflection for a project that has just begun. Unfortunately, gambling with its diverse negative outcomes, contributes to the formation of our cultural capital in the absence of strict regulations and urban policies. Do we consider gambling as part "of our unconscious collection of customs and beliefs and the feel for what is the right thing to do" which is one of the simplest definitions of the cultural capital (Kamphuis et al., 2015)? The answer is positive considering the emergence of gambling facilities that have opened in our cities. If adults gamble, we admit that they make conscious choices. The adolescents' attitude towards gambling remains problematic both as addictive behaviour and, in the long run, a problem of public health.

Pawn shops, besides showing the failure of the banking system to cope with the needs of the poor, insidiously completed the landscape of gambling - e.g. Eroilor de la Tisa Street -, placed so close to an emergent market made of the students residing on the campus of the University of Timișoara. The offers address both the sellers and buyers. Pawn shops sell the cheapest electronic appliances (laptops, computers, LCD screens/televisions, etc.) that students can use for their studies and also cell phones and jewellery.

The social patterns and cultural patterns so visible in our streets can easily promote fatalism. In Harvey's (2008, p. 91) perspective, our patterns of accepted practices and expectations that generate mutual behaviours and responses are four systems of negotiation: "consent, coercion, contract and convention". I still believe that for most of the gamblers, the consensual aspect prevails. Nevertheless, we must acknowledge that coercion, contract and convention follow up as parts of the social truth. "Coercion must be responsive to the collective 'demands' of the population" (Harvey, 2008, p. 97). In this situation, I have doubts about the freedom of the individuals to choose the strategic behaviour which best fits their social environment.

Our living environment is part of who we are, therefore our streets and public space represent an important legacy that we consciously, or not, leave to the next generation.

\section{Acknowledgements}

I thank the anonymous reviewers for their valuable suggestions. I also extend thanks to my friends Margareta Lelea and Alexandra zum Felde for the English language edits. 


\section{REFERENCES}

BOAS, F. (1888). The Central Eskimo. Sixth Annual Report. Bureau of Ethnology, Smithsonian Institution. Washington D.C., U.S.A.

CASOTA, F. (2016). Regele jocurilor de noroc din România [King of Gambling in Romania]. Business Magazine, 19.02.2016.

DOUGLAS, M. (2002) Natural Symbols, Explorations in Cosmolgy - With a New Introduction. London: Routledge.

CRETTAN, R., \& MATTHEWS, P.W. (2016). Popular Responses to City-Text Changes: Street Naming and the Politics of Practicality in a Post-Socialist Martyr City. Area, 48(1), 92-102.

GRĂDINARU, S.R., IOJĂ, C.I., ONOSE, D.A., GAVRILIDIS, A.A., PĂTRU-STUPARIU, I., KIENAST, F., \& HERSPERGER, A.M. (2015). Land Abandonment as a Precursor of Built-Up Development at the Sprawling Periphery of Former Socialist Cities. Ecological Indicators, 57, 305-313.

GRIFFITH, M. (2009). Problem Gambling in Europe: An Overview. London: Apex Communications.

HARVEY, D. (2008). A Conjecture on the Nature of Social Systems. 21st Century Society, 3(1), 87-108.

JUCU, S. (2015). Romanian Post-socialist Industrial Restructuring at the Local Scale: Evidence of Simultaneous Processes of De-/Reindustrialization in the Lugoj Municipality of Romania. Journal of Balkan and Near Eastern Studies, 17(4), 408-426.

KAMPHUIS, C.B.M., JANSEN, T., MACKENBACH, J.P., \& VAN LENTHE, F.J. (2015). Bourdieu's Cultural Capital in Relation to Food Choices: A Systematic Review of Cultural Capital Indicators and an Empirical Proof of Concept. PLoS ONE, 10(8), e0130695.

LAURIER, E. (2010). Participant Observation. In Clifford N., French S., Valentine G. (eds.), Key Methods in Geography, 2nd edition (pp. 116-130). London: Sage.

KRUEGER, R., \& CASEY, M.A. (2000). Focus Groups. A Practical Guide for Applied Research, 3rd edition. Thousand Oaks: Sage.

LEFEBVRE, H., \& NICHOLSON-SMITH, D. (1991). The Production of Space. London: Wiley-Blackwell.

LIU, W., LEE, G.P., GOlDWEBER, A., PETRAS, H., STORR, C.L., \& IALONGO, N., \& MARTINS, S.S. (2013). Impulsivity Trajectories and Gambling in Adolescence among Urban Male Youth. Addiction, 108(4), 780-788.

LONGHURST, L. (2010). Semi-structured Interviews and Focus Groups. In N. Clifford, S. French, \& G. Valentine (eds.), Key Methods in Geography, 2nd edition (pp. 103-115). London: Sage.

MAMADOUH, V. (1999). Grid-group Cultural Theory: An Introduction. GeoJournal, 47, 395-409.

MESSERLIAN, C., \& DEREVENSKY, J. (2007). Evaluating the Role of Social Marketing Campaigns to Prevent Youth Gambling Problems. Canadian Journal of Public Health, 98(2), 101-104.

PASTIA, E. (2005). Jocurile de noroc, sub asaltul crimei organizate [Gambling under Siege by Organised Crime]. Saptamana Financiară, 14.03.2005.

POPESCU, C. (2014). Deindustrialization and Urban Shrinkage in Romania. What Lessons for the Spatial Policy? Transy/vanian Review of Administrative Sciences, 42E, 181-202.

PRAȘCA, M., PETREA, R., \& ILIA FILIMON, M. (2013). The Urban Shrinkage of the Small Towns Located in Southern Part of Bihor County, Romania. Analele Universitătii din Oradea - Seria Geografie, XXIII(1), 172-180.

REITH, G., \& DOBBIE, F. (2011). Beginning Gambling: The Role of Social Networks and Environment. Addiction Research and Theory, 19(6), 483-493.

RELPH, E. (1976). Place and Placelessness. London: Pion. 
RELPH, E. (2000). Author's Response: Place and Placelessness in a New Context [Classics in Human Geography Revisited, Place and Placelessness]. Progress in Human Geography, 24(4), 613-619.

RINK, D., COUCH, C., HAASE, A., KRZYSZTOFIK, R., NADOLU, B., \& RUMPEL, P. (2014). The Governance of Urban Shrinkage in Cities of Post-Socialist Europe: Policies, Strategies and Actors. Urban Research \& Practice, 7(3), 258-277.

SANDU, A. (2016). A Comparative Study of the Urban Morphology in Europe Using GMES Urban Atlas: The Post-Socialist City vs. the Capitalist City (Romania vs. France). Proceedings of the International Multidisciplinary Scientific GeoConference SGEM, 3, 3-10.

SEAMON, D., \& SOWERS, J. (2008). Place and Placelesness, Edward Relph. In P. Hubbard, R. Kitchen, \& G. Vallentine (eds.), Key Texts in Human Geography (pp. 43-51). London: Sage.

STOKER, G. (2004). Designing Institutions for Governance in Complex Environments: Normative, Rational Choice and Cultural Institutional Theories Explored and Contrasted. ESCR Fellowship Paper No. 1.

TOMASCIUC, A.I., MIHAIL, E., HAPCIUC, O., \& IATTU, C. (2016). Spatial Accessibility and Public Transport Issues in Postsocialist Metropolitan Areas: A Case Study of Suceava (Romania). 16th International Multidisciplinary Scientific GeoConference SGEM2016 Conference Proceedings, 3, 431-438.

VEIGA, A., JOÃO ROSA, A., \& AMARAL, A. (2011). Understanding the Impacts of Quality Assessment: An Exploratory Use of Cultural Theory. Quality in Higher Education 17(1), 53-67.

VOICULESCU, S., \& JUCU, I.S. (2016). Producing Urban Industrial Derelict Places: The Case of the Solventul Petrochemical Plant in Timişoara. European Urban \& Regional Studies, 23(4), 765-781. 